\title{
Wood density variation of different provenance for exotic loblolly pine in China
}

\author{
$\mathrm{Xu}-$ Youming $^{1}$, Lin-Han $^{2}$, Zhen-Hongpo $^{3}$, Liu-Jihong $^{4}$, Zhou-Caixia $^{5}$ \\ College of Forestry and Horticulture, Huazhong Agricultural University, Wuhan 430070, P R China \\ Corresponding Authors: Dr Prof. Youming Xu
}

College of Forestry and Horticulture, Huazhong Agricultural University, Wuhan 430070, Hubei Province, P R China

Fax: 86-27-87282010

Tel: 86-27-87282010 (O), 86-18971560337

E-mail: xuyouming@mail.hzau.edu.cn

\begin{abstract}
Variation patterns and range of juvenile wood basic density (BD) of 30 loblolly pine provenances in Zhejiang Province of China were reported in this paper. There were four radial variation patterns of BD within 310 10-year-old trees of 30 provenances, but the main pattern was a steadily increasing trend from pith to bark. The early-late correlation coefficient of $B D$ for loblolly pine strengthens with trees age and the value of $B D$ in 5 years old trees can be used for predict that in 10 years old trees. The BD mean change of 30 provenances is similar to normal distribution and the BD varies from 0.343 to $0.412 \mathrm{~g} / \mathrm{cm} 3$. The $B D$ mean of the contrast provenance is $0.369 \mathrm{~g} / \mathrm{cm} 3$ and in medial level. There is an obvious difference in $B D$ among 30 provenances. Further analyses show that the difference among trees within a provenance is greater than that among provenances and the environment has significant effects on its $B D$. The broad heritability of $B D$ is 0.72. The individual tree selection within a provenance was much better than that among different provenance.
\end{abstract}

The BD mean of 30 provenances is related positively to the provenance latitude, Longitude of provenance is related negatively to wood density in East Coast and positive to wood density in South Coast and Gulf. There is a tendency for BD of loblolly pine provenance to be lower from west to east and from north to south. This variation in plantation in a common environment turned out contrary to that of natural at different environment. The BD of loblolly pine provenances introduced from high latitude is greater than that from low latitude, but tree growth properties from low latitude were much faster than those from high latitude.

The BD mean value of 310 trees at the same growth stage (the same age) was negatively related to the diameter at breast height and volume of these trees. Wood density was significant correlated negatively with tracheid width and tracheid diameter at different growth stage of loblolly pine. DBH was significant positively correlated with tracheid width, tracheid diameter and negatively distinct related to ratio of tracheid double wall thickness to tracheid diameter. That DBH was related positively to ratio of tracheid diameter to tracheid width and negatively to tracheid wall thickness showed that the tracheid wall thickness of fast trees or fast provenances did not increase in proportion as tracheid width and tracheid diameter increased. This would lead to the decrease in wood basic density. Better provenance selection for pulpwood and building lumber should be determined from both tree growth and wood properties.

Keywords — loblolly pine, wood density, variation, wood anatomy, provenance trial and correlation analyses.

\section{INTRODUCTION}

Pinus taeda $\mathrm{L}$ originated from the southeastern of the U. S. A. is one of the most important exotic species for wooden industrial materials in subtropical area of the world. It was first introduced to plant in China in 1933 (Peng, 1992). Now it is extensively planted on hilly lands and low mountains in the Southern China for pulpwood and building lumber. It was estimated that the areas of its plantation is at least more than one million hectares in 1995. Most of these stands for loblolly pine are 20 25 years old and do not look good in both its stem shape and wood quality. It is necessary for them to be replaced with better provenances of loblolly pine within 10 15 years.

Although loblolly pine has been culturing in China for more than seventy years, its provenance trial was not formally done until 1981 (Peng, 1992). According to the statistics in 1992 its seed orchard in China was about 809 hectares and its seed stand about 2720 hectares. Every year about 25000kg of seeds was imported from the American (Peng, 1992). The seed output is far from the demand of our forestry production and the genetic quality of seed is low. Because its natural growing range in the American is large and there are significant differences in its tree growth, resistance and wood quality among the seed sources (Zobel 1958 and 1989), it is significant to for us to select better provenance for tree growth and wood improvement (Liu 2010; Kimura 2014; Sharma 2015; Takeuchi 2016). 
In the United States wood properties of loblolly pine usually follow a rather predictable pattern (Koch 1972 and Zobel 1989). The inland and northern sources of loblolly pine have lower specific gravity and frequently shorter tracheid length than southern and coastal sources (Jackson and Strickland 1962, Mitchell 1964, Talbert and Jett 1981, Zobel 1958 and 1989). But the studies carried out by Byram (1980), Tauer (1990), Jayawickrama, Mckeand and Jett (1997) showed that wood properties of loblolly pine did not follow the rather predictable patterns. These showed the environment had a significant effect on variation of wood basic density for loblolly pine (Zobel 1989). What is about variation of wood basic density for loblolly pine provenance in China? Is there a rather predictable pattern in its wood basic density in China? We would like to know these answers. The provenance trial of loblolly pine organised by Chinese Academic of Forestry was carried out two times in 1981 and 1983 in China, respectively. The seeds for experiment in 1981 were collected from the natural stands and for experiment in 1983 were obtained from the improved seeds orchard of loblolly pine in United States (Peng 1992).

Wood density is an important index for both wood properties and wood improvement in tree breeding (Panshin 1980; Zobel 1984; Liu 2010; Kimura 2014; Sharma 2015; Takeuchi 2016). Its variation will affect wood quality, pulp yield per hectare, quality of paper and pulp and wood products. The objectives of this paper will study the variation patterns of wood basic density for loblolly pine on the bases of its provenance trial in 1983 in China. The results obtained will supply the theoretical bases in wood improvement of loblolly pine, its plantation culturing and reasonable and efficient utilizing of its wood resources.

\section{MATERIALS AND METHODS}

\section{$2.1 \quad$ Test materials}

The trial stand of 31 loblolly pine provenances was established in spring of 1993 in the Forest Farm of Fuyang County in Zhejing Province (in eastern of China). The Forest Farm is located at $119^{\circ} 58^{\prime} \mathrm{E}$ and $30^{\circ} 15^{\prime} \mathrm{N}$. Its annual rainfall is $1478 \mathrm{~mm}$ and means temperature is $15.6^{\circ} \mathrm{c}$. Its frostfree season is 221 days per year. The test stand is located at the hill of about $150 \mathrm{~m}$ $\sim 170 \mathrm{~m}$ height above sea level in the Forest Farm. Its site is red soil and within $60 \sim 80 \mathrm{~cm}$. The pH was about 5.1 .

The field plan of provenance was designed in form of randomized block, double lines in a block are twenty trees and replication number is five. Plant and row spacing in the test stand is $1.5 \times 2.5 \mathrm{~m}^{2}$. The seeds of 30 provenances provided by Forest Service of the American were separately collected from improved stands of twenty states in the southeastern of the American. The seeds collected from trees of loblolly pine planted in Wuhan in 1945 were tested together as a contrasting material. The geographical and meteorological factors of various provenances in their original regions were presented in Table 1.

\section{TABLE 1}

THE ORIGIN AND THE LOCAL FACTORS OF GEOGRAPHY AND METEOROLOGY OF 31 PROVENANCE

\begin{tabular}{|c|c|c|c|c|c|c|c|}
\hline Prov No & Geographic Location & Latitude & Longitude & Prov No & Geographic Location & Latitude & Longitude \\
\hline 1 CL-3 & Maryland Worcester & $38^{\circ} 15^{\prime}$ & $75^{\circ} 30^{\prime}$ & 17 RL-3 & Alabama Claoctaw & $32^{\circ}$ & $88^{\circ}$ \\
\hline $2 \mathrm{CL}-2$ & Virginia King \& Queen & $37^{\circ} 30^{\prime}$ & $77^{\circ}$ & 18 RL-2 & Alabama Buter & $31^{\circ} 30^{\prime}$ & $86^{\circ} 45^{\prime}$ \\
\hline 3 RL-1 & Virginia New Kent & $37^{\circ} 30^{\prime}$ & $77^{\circ}$ & 19 RL-1 & Alabama Dallas & $30^{\circ} 30^{\prime}$ & $87^{\circ}$ \\
\hline 4 CL-8 & Kentucky Ballard & $37^{\circ}$ & $89^{\circ}$ & 20 RL-8 & Alabama Monreo & $31^{\circ} 30^{\prime}$ & $87^{\circ}$ \\
\hline 5 RL-2 & North Carolina Gates & $36^{\circ} 30^{\prime}$ & $77^{\circ}$ & 21 RL-2 & Alabama Pickens & $33^{\circ}$ & $88^{\circ}$ \\
\hline $6 \quad$ RL-3 & North Carolina Anson & $35^{\circ}$ & $80^{\circ}$ & 22 RL-3 & Mississippi Jones & $31^{\circ} 30^{\prime}$ & $89^{\circ}$ \\
\hline 7 RL-5 & North Carolina Wayne & $35^{\circ}$ & $78^{\circ}$ & 23 RL-5 & Mississippi Franklin & $31^{\circ} 30^{\prime}$ & $91^{\circ}$ \\
\hline 8 RL-6 & South Carolina Georgetown & $34^{\circ}$ & $79^{\circ}$ & 24 RL-6 & Louisiana Livigston & $30^{\circ} 30^{\prime}$ & $91^{\circ}$ \\
\hline 9 RL-8 & South Carolina Greenwood & $34^{\circ} 15^{\prime}$ & $82^{\circ} 15^{\prime}$ & 25 RL-8 & Louisiana Grant Parish & $31^{\circ} 30^{\prime}$ & $92^{\circ}$ \\
\hline 10 RL-9 & South Carolina Sumter & $34^{\circ}$ & $80^{\circ} 30^{\prime}$ & 26 RL-8 & Louisiana Desoto & $32^{\circ}$ & $94^{\circ}$ \\
\hline $11 \mathrm{RL}-11$ & Georgia Bibb & $32^{\circ} 30^{\prime}$ & $83^{\circ} 45^{\prime}$ & 27 CL-8 & Texas Jasper & $36^{\circ}$ & $90^{\circ} 30^{\prime}$ \\
\hline 12 RL-12 & Georgia Stewart & $32^{\circ}$ & $84^{\circ} 45^{\prime}$ & $28 \quad$ CL-8 & Arkansas Pike & $34^{\circ}$ & $93^{\circ}$ \\
\hline 13 RL-14 & Georgia Evans & $32^{\circ} 0$ & $82^{\circ}$ & 29 CL-8 & Texas Marion & $33^{\circ}$ & $95^{\circ}$ \\
\hline 14 RL-20 & Geogia Margan & $33^{\circ} 30^{\prime}$ & $83^{\circ} 30^{\prime}$ & $30 \quad$ CL-8 & Texas Jasper & $31^{\circ}$ & $94^{\circ} 30^{\prime}$ \\
\hline $15 \mathrm{RL}-16$ & Florida Nassau & $30^{\circ} 30^{\prime}$ & $81^{\circ} 30^{\prime}$ & $31 \mathrm{CK}$ & Wuhan of China & $30^{\circ} 31^{\prime}$ & $114^{\circ} 29^{\prime} \mathrm{E}$ \\
\hline $16 \mathrm{RL}-17$ & Florida Marion & $29^{\circ}$ & $82^{\circ}$ & & Trial location & $30^{\circ} 31^{\prime}$ & $119^{\circ} 58^{\prime} \mathrm{E}$ \\
\hline
\end{tabular}

\subsection{Methods}

The trial stand's age of loblolly pine was 10 years old in 2003. At this time it was necessary for the trial stand to be thinned. The height and diameter at breast height of each tree in the stand were first measured before thinning. Then ten trees of each provenance from the trial stand (two trees per replication in each block) were selected to use as test material. After trees were cut down the diameter of $1 / 2$ height of each tree was measured. Based on the increments the volume of each tree was 
calculated. A round-timber about $2.7 \mathrm{~m}$ started at $1.2 \mathrm{~m}$ height from base to top was sawn from each tree. Totally 310 trees were collected for 31 provenances.

In the laboratory five clear sampled discs of about $2 \sim 4 \mathrm{~cm}$ in thickness were sawn near the breast height from a round-timber. These discs were used for measuring features of wood anatomy, basic density, shrinkage of wood and chemical composition of wood. 3 5 test specimens of each wood property were cut from pith to bark at each disk on the condition of the same ring age range. Measurements of ring width and latewood width were taken directly on the smooth discs processed with the help of a stereomicroscope fitted with a micrometer. Based on the measurement the latewood percentage could be calculated. Basic density of 1 3 rings, 4 5 rings and 6 9 rings were determined by the maximum moisture method of Smith in 1954, respectively.

After determination of basic density the wood of 1 3 rings, 4 5 rings and 6 9 rings was used for determining their tracheid anatomic features. First specimens of earlywood and latewood were macerated with Juffery's fluid respectively. Then tracheids were directly measured by projecting them on a screen $(40 \mathrm{~cm}$ diameter) at $50 \mathrm{X}$ or $100 \mathrm{X}$ magnification with a $35 \mathrm{~mm}$ slide projector. Thirty readings were made per sample, selecting randomly unbroken tracheid. The values of tracheid width, tracheid diameter and tracheid wall thickness were acquired directly on 20um thick cross microtome section with microscope at 400X magnification, selecting thirty cells separately from earlywood to latewood to be determined.

The specific weighted mean values for the 1 5 rings and the 1 9 rings in tracheid anatomic features were calculated on the bases of the mean values measured of 1 3 rings, 4 5 rings and 6 9 rings according to the percentages of their rings width in total width of the rings range.

With the SAS, the difference of wood basic density among provenances of loblolly pine was analyzed and the relationships between basic density and anatomic characteristics of provenances to their geographic and meteorology factors were assessed.

\section{RESUlTS AND ANALYSES}

\subsection{Radial variant pattern of trees within a provenance of loblolly pine}

TABLE 2

VARIANT PATTERNS OF WOOD BASIC DENSITY WITHIN TREES FOR EXOTIC LOBLOLLY PINE PROVENANCE

\begin{tabular}{|c|c|c|c|c|c|c|c|c|c|}
\hline $\begin{array}{l}\text { Prov. } \\
\text { No }\end{array}$ & $\begin{array}{l}\text { Pattern I } \\
\text { No } \%\end{array}$ & $\begin{array}{c}\text { Pattern II } \\
\text { No } \%\end{array}$ & $\begin{array}{l}\text { Pattern III } \\
\text { No } \%\end{array}$ & $\begin{array}{l}\text { Pattern IV } \\
\text { No } \%\end{array}$ & $\begin{array}{l}\text { Prov. } \\
\text { No }\end{array}$ & $\begin{array}{l}\text { Pattern I } \\
\text { No } \%\end{array}$ & $\begin{array}{c}\text { Pattern II } \\
\text { No } \%\end{array}$ & $\begin{array}{l}\text { Pattern III } \\
\text { No } \%\end{array}$ & $\begin{array}{c}\text { Pattern IV } \\
\text { No } \%\end{array}$ \\
\hline 1 & $6 \quad 60$ & $2 \quad 20$ & $2 \quad 20$ & $\begin{array}{ll}0 & 0\end{array}$ & 17 & $6 \quad 60$ & $\begin{array}{ll}0 & 0\end{array}$ & $4 \quad 40$ & $\begin{array}{ll}0 & 0\end{array}$ \\
\hline 2 & $\begin{array}{ll}5 & 50 \\
\end{array}$ & $\begin{array}{ll}0 & 0 \\
\end{array}$ & $\begin{array}{ll}4 & 40 \\
\end{array}$ & $\begin{array}{ll}1 & 10 \\
\end{array}$ & 18 & $\begin{array}{ll}7 & 70 \\
\end{array}$ & 110 & 220 & $\begin{array}{ll}0 & 0 \\
\end{array}$ \\
\hline 3 & $\begin{array}{ll}7 & 70 \\
\end{array}$ & $\begin{array}{ll}3 & 30 \\
\end{array}$ & $\begin{array}{ll}0 & 0 \\
\end{array}$ & $\begin{array}{ll}0 & 0 \\
\end{array}$ & 19 & 50 & 440 & 10 & $\begin{array}{ll}0 & 0 \\
\end{array}$ \\
\hline 4 & $\begin{array}{ll}7 & 70 \\
\end{array}$ & 10 & 220 & 0 & 20 & 50 & 220 & 30 & $\begin{array}{ll}0 & 0 \\
\end{array}$ \\
\hline 5 & $\begin{array}{ll}9 & 90 \\
\end{array}$ & $\begin{array}{ll}1 & 10 \\
\end{array}$ & 0 & 0 & 21 & 80 & $\begin{array}{ll}0 & 0 \\
\end{array}$ & $\begin{array}{ll}2 & 20 \\
\end{array}$ & $\begin{array}{ll}0 & 0 \\
\end{array}$ \\
\hline 6 & $\begin{array}{ll}7 & 70 \\
\end{array}$ & $\begin{array}{ll}0 & 0 \\
\end{array}$ & \begin{tabular}{|ll}
3 & 30 \\
\end{tabular} & 0 & 22 & 70 & 220 & 10 & $\begin{array}{ll}0 & 0 \\
\end{array}$ \\
\hline 7 & $\begin{array}{ll}6 & 60 \\
\end{array}$ & $\begin{array}{ll}0 & 0 \\
\end{array}$ & $\begin{array}{ll}4 & 40 \\
\end{array}$ & 0 & 23 & $\begin{array}{ll}7 & 70 \\
\end{array}$ & $0 \quad 0$ & $3 \quad 30$ & $\begin{array}{ll}0 & 0 \\
\end{array}$ \\
\hline 8 & $\begin{array}{ll}7 & 70 \\
\end{array}$ & 220 & 10 & 0 & 24 & $\begin{array}{ll}8 & 80 \\
\end{array}$ & $\begin{array}{ll}1 & 10\end{array}$ & 10 & $\begin{array}{ll}0 & 0 \\
\end{array}$ \\
\hline 9 & $\begin{array}{ll}6 & 60 \\
\end{array}$ & $\begin{array}{ll}0 & 0 \\
\end{array}$ & $\begin{array}{ll}4 \quad 40 \\
\end{array}$ & $\begin{array}{ll}1 & 10 \\
\end{array}$ & 25 & $\begin{array}{ll}10 & 100 \\
\end{array}$ & $\begin{array}{ll}0 & 0 \\
\end{array}$ & 0 & $\begin{array}{ll}0 & 0 \\
\end{array}$ \\
\hline 10 & $\begin{array}{ll}6 & 60 \\
\end{array}$ & $\begin{array}{ll}10 \\
\end{array}$ & 30 & $\begin{array}{ll}0 & 0 \\
\end{array}$ & 26 & $\begin{array}{ll}7 & 70 \\
\end{array}$ & 110 & 20 & $\begin{array}{ll}0 & 0 \\
\end{array}$ \\
\hline 11 & $\begin{array}{ll}4 & 40 \\
\end{array}$ & $\begin{array}{ll}3 & 30 \\
\end{array}$ & $\begin{array}{ll}3 & 30 \\
\end{array}$ & 0 & 27 & 80 & 110 & 10 & $\begin{array}{ll}0 & 0 \\
\end{array}$ \\
\hline 12 & $\begin{array}{ll}10 & 100\end{array}$ & $\begin{array}{ll}0 & 0 \\
\end{array}$ & $\begin{array}{ll}0 & 0 \\
\end{array}$ & 0 & 28 & 90 & $\begin{array}{ll}0 & 0 \\
\end{array}$ & 0 & $\begin{array}{ll}110 \\
\end{array}$ \\
\hline 13 & $\begin{array}{ll}7 & 70 \\
\end{array}$ & 220 & $\begin{array}{ll}1 & 10 \\
\end{array}$ & 0 & 29 & 80 & $\begin{array}{ll}1 & 10 \\
\end{array}$ & 10 & $\begin{array}{ll}0 & 0 \\
\end{array}$ \\
\hline 14 & $\begin{array}{ll}8 & 80 \\
\end{array}$ & $\begin{array}{ll}0 & 0 \\
\end{array}$ & 20 & $\begin{array}{ll}0 & 0 \\
\end{array}$ & 30 & 60 & $\begin{array}{ll}1 & 10 \\
\end{array}$ & 20 & 110 \\
\hline 15 & 90 & $\begin{array}{ll}0 & 0 \\
\end{array}$ & 0 & $\begin{array}{ll}1 & 10 \\
\end{array}$ & 31 & $\begin{array}{ll}7 & 70\end{array}$ & $\begin{array}{ll}0 & 0 \\
\end{array}$ & 20 & 110 \\
\hline 16 & 80 & $\begin{array}{ll}1 & 10 \\
\end{array}$ & 10 & 0 & Total & 22070.9 & $\begin{array}{ll}29 & 9.4 \\
\end{array}$ & 17.7 & $\begin{array}{ll}6 & 1.9 \\
\end{array}$ \\
\hline
\end{tabular}

The results showed that there were four kinds of radial variant patterns within trees of 31 peovenancs for exotic loblolly pine. In Table 2, the pattern I was wood basic density first increasing from pith to bark within trees. The possibility range of the pattern I that appeared was from $40 \%$ to $100 \%$ with a provenance and its mean possibility was $71 \%$. The pattern II was basic density first increasing from pith to bark within trees, then decreasing; The possibility range of the pattern II which appeared was from $10 \%$ to $40 \%$ with a provenance and its mean possibility was $9.4 \%$. The pattern III was first decreasing slightly in radial direction, then increasing and the possibility range of the pattern III which appeared was from $10 \%$ to $40 \%$ with a provenance and its mean possibility $17.7 \%$. The pattern IV was decreasing in radial direction and its mean possibility appeared was $1.9 \%$. It was seen that the main patterns were I and III. Therefore there were $71 \%$ to $88.6 \%$ possibility that variation of basic density in radial direction for juvenile loblolly pine increased from pith to bark, which was in accordance with the radial variation pattern of specific gravity within trees of loblolly pine conducted by Loo and McNee in 1985 . The 
mean value of wood basic density for 1 3 rings in redial direction on the 300 discs of 30 loblolly pine (except the Prov. 31 ) was $0.339 \mathrm{~g} / \mathrm{cm}^{3}$, the $4 \sim 5$ rings was $0.377 \mathrm{~g} / \mathrm{cm}^{3}$ and the $6 \sim 7$ rings was $0.419 \mathrm{~g} / \mathrm{cm}^{3}$. Totally basic density showed increasing pattern and unstable from pith to bark within trees. Because there are four radial patterns for wood density in stands of juvenile loblolly pine and variation of its wood density is unstable, the number of specimens and the ring age range are important in order to get the right result in wood improvement.

\subsection{Early - late relationship of wood basic density for loblolly pine at different growth stage}

The short rotation of loblolly pine plantation for pulpwood is about 10 15 years and its rotation for building lumber is about 25 30 years in China. It is significant for us to know the early-late relationship of its wood basic density at different growth stage in wood improvement. In table 3 relationship coefficients of wood basic density between the 3-year-old trees and 5year-old trees for 30 provenances were from 0.1167 to 0.9514 . Relationship coefficients of 26 provenances were found to be statistically significant at the 95 percent level of confidence $\left(r_{0.05}=0.6030, \mathrm{n}=10\right)$ and their proportions were $76.7 \%$ within 30 provenances. The relationship coefficients of wood basic density between the 3 -year-old trees and 9-year-old trees were from 0.2994 to 0.9356 for 30 provenances. 22 provenances were statistically significant at the 95 percent level of confidence and their proportions were $73.7 \%$. The relationship coefficients of wood basic density between 5-year-old trees and 9-yearold trees for 30 provenances were from 0.6515 to 0.9579 . All provenances were found to be statistically significant at the 95 percent level of confidence and 24 provenances were statistically significant at the 99 percent level of confidence. These reflected that the relationship property of wood basic density for loblolly pine was strengthened as tree age. Hence the value of wood basic density for 5-year-old loblolly pine could be used as a predicting index of 10-year-old loblolly pine for pulpwood.

TABLE 3

EARLY-LATE RELATIONSHIP COEFFICIENTS OF WOOD BASIC DENSITY FOR LOBLOLLY PINE PROVENANCE AT DIFFERENT GROWTH STAGE

\begin{tabular}{|c|c|c|c|c|c|c|c|}
\hline $\begin{array}{c}\text { Prov. } \\
\text { No. }\end{array}$ & Early age & \multicolumn{2}{|c|}{$\frac{\text { Late estimated age of trees }}{5-\text { year-old } 9 \text {-year-old }}$} & \multirow{2}{*}{$\begin{array}{c}\text { Prov. } \\
\text { No. } \\
16\end{array}$} & \multirow{2}{*}{$\begin{array}{l}\text { Early age } \\
\text { 3-year-old } \\
\text { 5-year-old }\end{array}$} & \multicolumn{2}{|c|}{ Late estimated age of trees } \\
\hline 1 & $\begin{array}{l}3 \text {-year-old } \\
5 \text {-year-old }\end{array}$ & $0.7377 *$ & $\begin{array}{l}0.8383 * * * \\
0.9738^{* * *}\end{array}$ & & & $0.8913 * * *$ & $\begin{array}{l}0.8041^{* *} \\
0.9255^{* * *}\end{array}$ \\
\hline 2 & $\begin{array}{l}3 \text {-year-old } \\
5 \text {-year-old }\end{array}$ & 0.4105 & $\begin{array}{c}0.5743 \\
0.9035^{* * *} \\
\end{array}$ & 17 & $\begin{array}{l}\text { 3-year-old } \\
5 \text {-year-old }\end{array}$ & $0.7665 * *$ & $\begin{array}{l}0.8499 * * * \\
0.9698 * * *\end{array}$ \\
\hline 3 & $\begin{array}{l}3 \text {-year-old } \\
5 \text {-year-old }\end{array}$ & $0.6621 *$ & $\begin{array}{c}0.6570^{*} \\
0.9665^{* * *}\end{array}$ & 18 & $\begin{array}{l}3 \text {-year-old } \\
5 \text {-year-old }\end{array}$ & $0.6395 *$ & $\begin{array}{l}0.8618 * * * \\
0.8978 * * *\end{array}$ \\
\hline 4 & $\begin{array}{l}3 \text {-year-old } \\
5 \text {-year-old }\end{array}$ & $0.8741 * * *$ & $\begin{array}{l}0.8530 * * * \\
0.9727 * * *\end{array}$ & 19 & $\begin{array}{l}\text { 3-year-old } \\
5 \text {-year-old }\end{array}$ & $0.8481 * * *$ & $\begin{array}{l}0.8777 * * * \\
0.9759 * * *\end{array}$ \\
\hline 5 & $\begin{array}{l}3 \text {-year-old } \\
5 \text {-year-old }\end{array}$ & $0.8280 * * *$ & $\begin{array}{c}0.4501 \\
0.9645^{* * *}\end{array}$ & 20 & $\begin{array}{l}3 \text {-year-old } \\
5 \text {-year-old }\end{array}$ & 0.5093 & $\begin{array}{l}0.7981 * * * \\
0.8913 * * *\end{array}$ \\
\hline 6 & $\begin{array}{l}3 \text {-year-old } \\
5 \text {-year-old }\end{array}$ & $0.7260 * * *$ & $\begin{array}{c}0.2994 \\
0.8385^{* * *}\end{array}$ & 21 & $\begin{array}{l}3 \text {-year-old } \\
5 \text {-year-old }\end{array}$ & 0.5790 & $\begin{array}{c}0.6946 * \\
0.9448 * * *\end{array}$ \\
\hline 7 & $\begin{array}{l}\text { 3-year-old } \\
5 \text {-year-old }\end{array}$ & 0.3794 & $\begin{array}{l}0.4276 * * * \\
0.9051 * * *\end{array}$ & 22 & $\begin{array}{l}\text { 3-year-old } \\
5 \text {-year-old }\end{array}$ & 0.6032 & $\begin{array}{c}0.6747 * \\
0.9257 * * *\end{array}$ \\
\hline 8 & $\begin{array}{l}3 \text {-year-old } \\
5 \text {-year-old }\end{array}$ & $0.8029 * *$ & $\begin{array}{l}0.9074 * * * \\
0.8997 * * *\end{array}$ & 23 & $\begin{array}{l}3 \text {-year-old } \\
5 \text {-year-old }\end{array}$ & $0.7085^{* *}$ & $\begin{array}{l}0.7794 * * \\
0.9571 * * *\end{array}$ \\
\hline 9 & $\begin{array}{l}\text { 3-year-old } \\
5 \text {-year-old }\end{array}$ & $0.8742 * * *$ & $\begin{array}{l}0.8994 * * * \\
0.9795 * * *\end{array}$ & 24 & $\begin{array}{l}3 \text {-year-old } \\
5 \text {-year-old }\end{array}$ & $0.6537^{*}$ & $\begin{array}{l}0.8446 * * * \\
0.9251 * * *\end{array}$ \\
\hline 10 & $\begin{array}{l}3 \text {-year-old } \\
5 \text {-year-old }\end{array}$ & $0.9514 * * *$ & $\begin{array}{l}0.9356 * * * \\
0.9727 * * *\end{array}$ & 25 & $\begin{array}{l}3 \text {-year-old } \\
5 \text {-year-old }\end{array}$ & $0.6442 *$ & $\begin{array}{c}0.3423 \\
0.8757 * * *\end{array}$ \\
\hline 11 & $\begin{array}{l}\text { 3-year-old } \\
\text { 5-year-old }\end{array}$ & 0.1167 & $\begin{array}{c}0.5540 \\
0.6515^{*}\end{array}$ & 26 & $\begin{array}{l}\text { 3-year-old } \\
5 \text {-year-old }\end{array}$ & $0.8417 * * *$ & $\begin{array}{l}0.8763 * * * \\
0.9721 * * *\end{array}$ \\
\hline 12 & $\begin{array}{l}3 \text {-year-old } \\
5 \text {-year-old }\end{array}$ & $0.8701 * * *$ & $\begin{array}{c}0.7760 * * \\
0.9377 * * *\end{array}$ & 27 & $\begin{array}{l}3 \text {-year-old } \\
5 \text {-year-old }\end{array}$ & 0.3384 & $\begin{array}{c}0.5078 \\
0.8968^{* * *}\end{array}$ \\
\hline 13 & $\begin{array}{l}3 \text {-year-old } \\
5 \text {-year-old }\end{array}$ & $0.9088^{* * *}$ & $\begin{array}{l}0.8906 * * * \\
0.9550 * * *\end{array}$ & 28 & $\begin{array}{l}3 \text {-year-old } \\
5 \text {-year-old }\end{array}$ & $0.6721 *$ & $\begin{array}{l}0.9135 * * * \\
0.8801 * * *\end{array}$ \\
\hline 14 & $\begin{array}{l}3 \text {-year-old } \\
5 \text {-year-old }\end{array}$ & 0.4002 & $\begin{array}{c}0.4762 \\
0.9560^{* * *} \\
\end{array}$ & 29 & $\begin{array}{l}3 \text {-year-old } \\
5 \text {-year-old }\end{array}$ & $0.8419 * * *$ & $\begin{array}{l}0.8464 * * * \\
0.8583 * * *\end{array}$ \\
\hline 15 & $\begin{array}{l}3 \text {-year-old } \\
5 \text {-year-old }\end{array}$ & $0.7746 * * *$ & $\begin{array}{l}0.7053 \text { *** } \\
0.9549 \text { *** }\end{array}$ & 30 & $\begin{array}{l}3 \text {-year-old } \\
5 \text {-year-old }\end{array}$ & $0.7360 * *$ & $\begin{array}{c}0.6488 * \\
0.9198 * * *\end{array}$ \\
\hline
\end{tabular}




\subsection{The difference analyses of wood basic density among provenances}

Variance analyses in Table 4 showed that there was an obvious difference in wood basic density among 31 provenances for loblolly pine. According to the simple equation $\left(\mathrm{h}_{\mathrm{f}}{ }^{2}=(1-1 / \mathrm{F})^{1 / 2}\right.$ of broad sense heritability, $\mathrm{h}_{\mathrm{f}}{ }^{2}=0.7215$. These showed that provenance selection in this trial was effective. Of 31 provenances in Table 5, basic density of No 26 was the highest $(0.416$ $\left.\mathrm{g} / \mathrm{cm}^{3}\right)$ and that of No 12 the smallest $\left(0.343 \mathrm{~g} / \mathrm{cm}^{3}\right)$. Their difference was $0.073 \mathrm{~g} / \mathrm{cm}^{3}$ and the percentage $29 \%$. Basic density of the contrasting provenance (No.31) was $0.369 \mathrm{~g} / \mathrm{cm}^{3}$ and in middle level. Duncan's multiple range's test in Table 5 indicated the obvious statistically differences in Table 4 existed only among parts of 31 provenance. For most of 31 provenances, their differences were not significant. This could be verified from the value of variation coefficient (C. V.) for 30 provenances in Table 6. For example, the C. V. of No.10 was the maximum and its value 13.5\%; The difference in basic density between trees within No.10 provenance was $0.145 \mathrm{~g} / \mathrm{cm}^{3}$. The difference in basic density between trees within No.26 with the highest wood density was $0.105 \mathrm{~g} / \mathrm{cm}^{3}$ and the difference in basic density between trees within No 12 with smallest wood density was $0.055 \mathrm{~g} / \mathrm{cm}^{3}$. The variant range of wood basic density for No.31 (the contrasting material) was from 0.327 $\mathrm{g} / \mathrm{cm}^{3}$ to $0.429 \mathrm{~g} / \mathrm{cm}^{3}$ and the difference was $0.102 \mathrm{~g} / \mathrm{cm}^{3}$. Population mean value of wood basic density for 31 provenance was $0.372 \mathrm{~g} / \mathrm{cm}^{3}$ and its $\mathrm{C}$. V. was only $5.0 \%$ among 31 provenances, which was almost less than C. V. between trees of each provenance except No.27 and No.30. These showed that the difference among trees within a given provenance was greater than that among provenance, i.e., there was much larger difference between trees within a provenance. Hence individual tree selection within a better provenance was much better than that among different provenance.

TABLE 4

VARIANCE ANALYSES OF WOOD BASIC DENSITY AMONG 31 PROVENANCE FOR 10-YEAR-OLD LOBLOLLY PINE

\begin{tabular}{|c|c|c|c|c|c|c|}
\hline Variance source & Df & S. S. & M. S. & F-value & Viarance Proportion (\%) & $\mathbf{h}_{\mathbf{f}}{ }^{2}$ \\
\hline Provenance & 30 & 0.49310 & 0.0016433 & $3.60^{* * *}$ & 43.57 & 0.7215 \\
\hline Block & 4 & 0.00839 & 0.0023232 & & 7.89 & \\
\hline Error & 120 & 0.05492 & 0.0004577 & & 48.54 & \\
\hline
\end{tabular}

Among the total variance in table 4 proportion of provenance variance was $43.57 \%$ and that of environment $56.43 \%$. This revealed that environment had a great significance effect on wood density. This showed that planting site and better silviculture practices were important for increasing growth increment and improving wood quality of loblolly pine. In culturing plantation of loblolly pine for pulpwood and building lumber better provenance should be combined together with selecting good site.

\subsection{Relationship analyses of wood basic density to latewood percent and trees growth increments}

In Fig.1 latewood percent and wood basic density in radial direction within trees increased as trees age. Wood basic density was positively significant related to latewood percent and their correlation coefficient was $0.4905\left(\mathrm{n}=31, \mathrm{r}_{0.01}=0.4487\right)$. These were in accordance with the research results (Pashin 1980 and Zobel 1989). Among provenances correlation coefficient of wood basic density with tree increments were 0.1285 in tree height, -0.4045 in DBH and -0.3535 in tree volume with simple linear model, respectively. It was found that the negative relationships of wood basic density to DBH and tree volume were significant $\left(n=31, r_{0.05}=0.3493\right)$ at the 95 percent level of confidence. For example, the growth increments of provenances of No.10, No.13, No.15, No.22, No.25, No.31 in Table 5 were much better than the rest of 31 provenances, but their wood density were less than the population mean. These indicated that better provenance should be selected from tree growth increment and wood properties because a little change $\left(0.04 \mathrm{~g} / \mathrm{cm}^{3}\right)$ of wood density would cause a great change in weight of wood dried per hectare (Zobel 1989). For pulpwood of short rotation the weighted value of tree growth increments could be increased in better provenance selection. To wood structural material wood quality should be much considered in its better provenances selection.

The mean values of wood density, tree height, DBH and tree volume for 31 provenance in Table 5 were $0.372 \mathrm{~g} / \mathrm{cm}^{3}, 6.47 \mathrm{~m}$, $9.68 \mathrm{~cm}$ and $0.0263 \mathrm{~m}^{3}$ and their weighted values were $0.45,0.10,0.20,0.35$ in order. The formula

$$
\mathrm{Si}=(45 *(\mathrm{BDi}-0.372) / 0.372)+(15 *(\mathrm{Hi}-6.47) / 6.47)+(20 *(\mathrm{Di}-9.68) / 9.68)+(30 *(\mathrm{Vi}-0.0263) / 0.0263)
$$

was utilized to calculate the Score of each provenance. If $\mathrm{Si}$ of a provenance $>0$, it ranked above the middle level. If $\mathrm{Si}<0$, it ranked below the middle level. The bigger the $\mathrm{Si}$, the better the provenance will be. Finally the provenances of No.15, No.10, No.13, No.31, No.26, No.20 and No.25 as better provenances for pulpwood were selected comprehensively out from tree increment and wood density. 


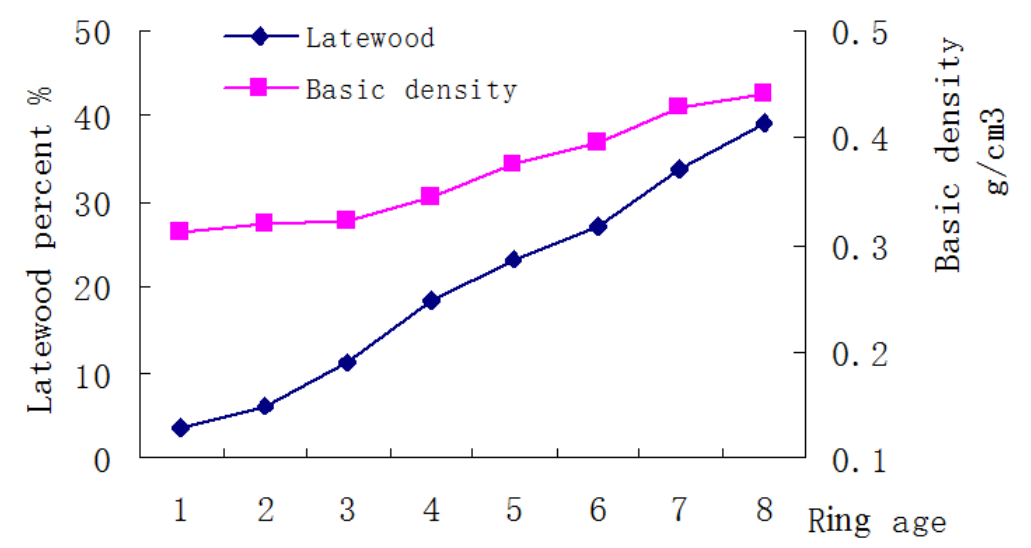

FIG 1: RELATIONSHIP OF WOOD BASIC DENSITY TO LATEWOOD PERCENTAGE

TABLE 5

DUNCAN'S MULTIPLE RANGE TEST AND THE SCORES OF EACH PROVENANCE FORM TREE GROWTH AND WOOD QUALITY

\begin{tabular}{|c|c|c|c|c|c|c|c|}
\hline $\begin{array}{l}\text { Prov } \\
\text { No. }\end{array}$ & $\begin{array}{c}\text { Basic density } \\
(\mathrm{g} / \mathrm{cm} 3)\end{array}$ & $\begin{array}{c}\alpha=0.05 \\
\text { level }\end{array}$ & $\begin{array}{c}\alpha=0.01 \\
\text { level }\end{array}$ & $\begin{array}{l}\text { Tree height } \\
\text { (m) }\end{array}$ & $\begin{array}{l}\text { DBH } \\
(\mathrm{cm})\end{array}$ & $\begin{array}{l}\text { Volume } \\
\left(\mathrm{m}^{3}\right)\end{array}$ & Score \\
\hline 26 & 0.416 & $\mathrm{~A}^{1}$ & $\mathrm{~A}$ & 7.08 & 9.15 & 0.0263 & $5.7 *$ \\
\hline 30 & 0.412 & $\mathrm{Ab}$ & $\mathrm{Ab}$ & 6.63 & 9.48 & 0.0236 & 1.6 \\
\hline 27 & 0.403 & $\mathrm{Abc}$ & $\mathrm{Abc}$ & 6.56 & 8.85 & 0.0248 & 0.6 \\
\hline 23 & 0.397 & Abcd & Abcd & 6.57 & 9.35 & 0.0264 & 2.7 \\
\hline 18 & 0.396 & Abcde & Abcd & 6.74 & 9.45 & 0.0256 & -1.1 \\
\hline 19 & 0.391 & Abcdef & Abcd & 6.34 & 8.90 & 0.0267 & 0.8 \\
\hline 5 & 0.384 & Abcdef & Abcd & 6.07 & 9.30 & 0.0246 & -2.2 \\
\hline 1 & 0.383 & Abcdef & Abcd & 6.15 & 9.07 & 0.0218 & -5.8 \\
\hline 28 & 0.382 & Abcdef & Abcd & 6.60 & 9.25 & 0.0243 & -1.7 \\
\hline 4 & 0.377 & Abcdef & Abcd & 6.63 & 9.58 & 0.0266 & 1.2 \\
\hline 20 & 0.377 & Abcdef & Abcd & 6.57 & 10.23 & 0.0286 & $4.7 *$ \\
\hline 21 & 0.372 & Abcdef & Abcd & 6.43 & 9.23 & 0.0263 & -1.0 \\
\hline 17 & 0.371 & Abcdef & Abcd & 6.46 & 10.10 & 0.0265 & 0.5 \\
\hline 29 & 0.370 & Abcdef & Abcd & 6.67 & 10.47 & 0.0295 & -5.5 \\
\hline 2 & 0.370 & Abcdef & Abcd & 5.55 & 8.12 & 0.0169 & -16.3 \\
\hline 31 & 0.369 & Abcdef & Abcd & 6.58 & 10.95 & 0.0330 & $10.1 * *$ \\
\hline 24 & 0.368 & Abcdef & Abcd & 6.57 & 9.07 & 0.0232 & -5.0 \\
\hline 10 & 0.368 & Abcdef & Abcd & 6.72 & 11.12 & 0.0368 & $15.0 * *$ \\
\hline 11 & 0.365 & Abcdef & Abcd & 6.30 & 9.85 & 0.0232 & -4.4 \\
\hline 7 & 0.365 & Abcdef & Abcd & 5.79 & 10.08 & 0.0245 & -3.6 \\
\hline 25 & 0.364 & Abcdef & Abcd & 7.00 & 10.27 & 0.0288 & 4.3 \\
\hline 3 & 0.363 & Abcdef & Abcd & 6.51 & 8.92 & 0.0259 & -2.9 \\
\hline 6 & 0.363 & Abcdef & Abcd & 6.17 & 9.60 & 0.0274 & -0.7 \\
\hline 8 & 0.363 & Abcdef & Abcd & 6.27 & 9.53 & 0.0229 & -5.8 \\
\hline 22 & 0.363 & Abcdef & Abcd & 6.30 & 9.60 & 0.0250 & -3.1 \\
\hline 9 & 0.356 & Bcdef & Abcd & 6.10 & 9.22 & 0.0233 & -7.1 \\
\hline 13 & 0.355 & Cdef & Abcd & 6.82 & 11.07 & 0.0347 & $11.2 * *$ \\
\hline 16 & 0.348 & Cdef & Abcd & 6.35 & 10.10 & 0.0265 & -2.1 \\
\hline 14 & 0.347 & Ef & Bcd & 6.07 & 9.52 & 0.0235 & -7.4 \\
\hline 15 & 0.346 & Ef & $\mathrm{Cd}$ & 7.23 & 11.90 & 0.0370 & $15.2 * *$ \\
\hline 12 & 0.343 & $\mathrm{f}$ & $\mathrm{D}$ & 6.61 & 9.33 & 0.0237 & -6.9 \\
\hline
\end{tabular}

${ }^{I}$ Values sharing the same letter are not significantly different at the 0.05 and 0.01 levels.

3.5 Relationship analyses of wood basic density to the factors of provenance's geography and meteorology in their indigenous regions

Considering the physical features of the USA topography and the distribution of provenances (seen in Fig 2), the natural range areas of loblolly pine were divided into three parts so that the relationship of wood density to the geographic and 
meteorological factors of provenances in each part was further analyzed. The provenance number of East Coast, South Coast and Mexico Gulf and Hinterland districts was 15, 14 and 6 separately.

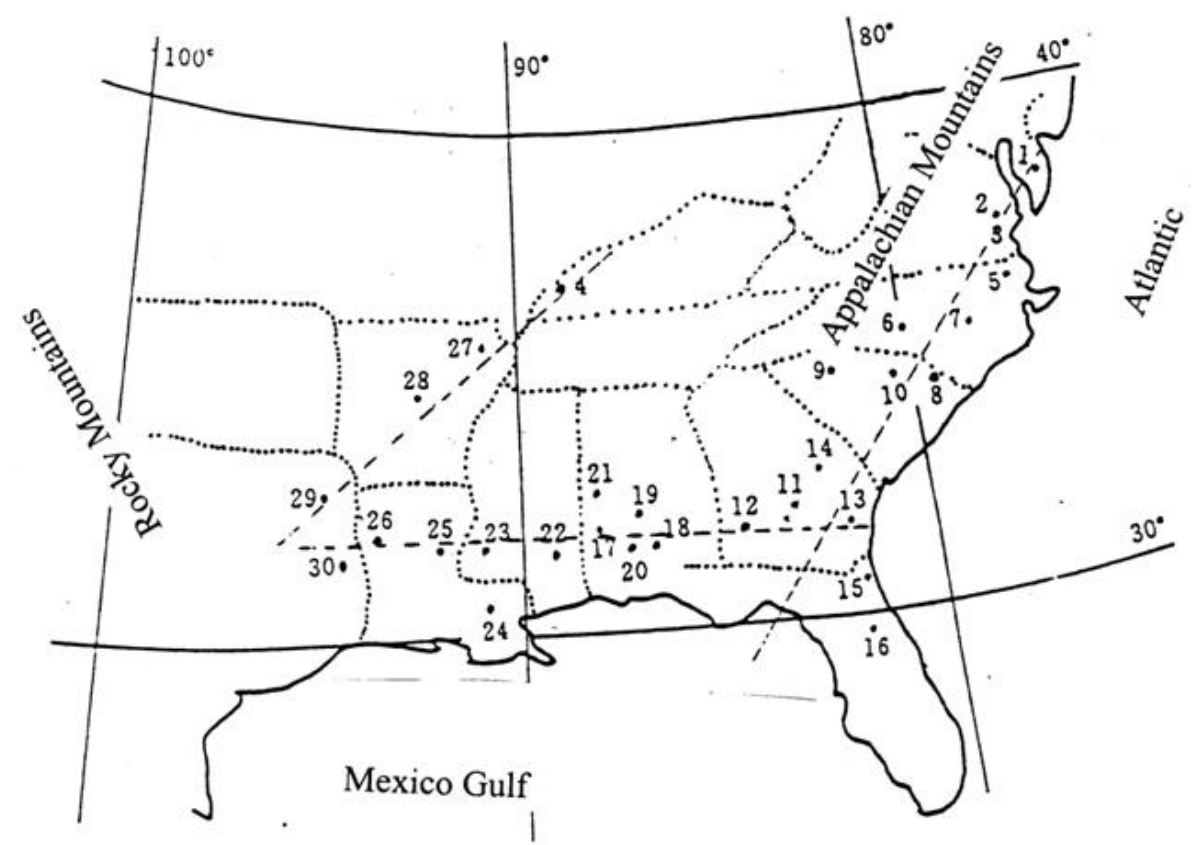

\section{FIG 2: THE LOCAL DISTRIBUTION OF 30 PROVENANCES FOR EXOTIC LOBLOLLY PINE AND THE NUMBER OF THEIR CODE.}

Wood density in Table 6 was correlated positively with latitude, annual rainfall and forstfree season, and negatively with longitude and annual mean temperature. This simple linear regression showed that the five local factors of latitude, longitude, annual rainfall and forstfree season for 15 provenances in East Coast districts near Atlantic had significant effects on wood basic density of loblolly pine $\left(r_{0.01}=0.6055, n=15\right)$. It was seen that annual mean temperature and forstfree season were main factors of affecting wood density from the magnitude of deviation regression coefficient. Actually this reflected the effect of latitude on wood basic density. This showed that the wood of provenances from higher latitude planted in lower latitude districts like our trial location had higher wood density and the wood from lower latitude had lower wood density. These were in accordance with the research results reported by Jackson (1962), Byram (1988) and Tauer (1990).

TABLE 6

CORRELATION COEFFICIENT OF WOOD DENSITY WITH THE FACTORS OF PROVENANCE'S GEOGRAPHY AND METEOROLOGY IN THEIR LOCAL REGIONS

\begin{tabular}{|c|c|c|c|c|c|c|c|}
\hline District & Item & Latitude & Longitude & $\begin{array}{c}\text { Annual } \\
\text { mean } \\
\text { temperature }\end{array}$ & $\begin{array}{l}\text { Annual } \\
\text { rainfall }\end{array}$ & $\begin{array}{l}\text { Forstfree } \\
\text { season }\end{array}$ & Notes \\
\hline East coast & Simple regression & $0.7838 * *$ & $-0.7893 * *$ & $-0.6901 * *$ & $0.6975 * *$ & $0.7089 * *$ & \multirow{2}{*}{$\begin{array}{c}\mathrm{r}_{0.05}=0.6055 \\
\mathrm{n}=15\end{array}$} \\
\hline & Deviation regression & 0.2460 & -0.3439 & 0.3855 & -0.1107 & -0.3857 & \\
\hline \multirow{2}{*}{$\begin{array}{c}\text { South coast and } \\
\text { Mexico gulf }\end{array}$} & Simple regression & 0.3554 & $0.5874 *$ & -0.4067 & -0.1818 & $-0.4901 *$ & \multirow{2}{*}{$\begin{array}{c}\mathrm{r}_{0.05}=0.4638 \\
\mathrm{n}=14\end{array}$} \\
\hline & Deviation regression & -0.1127 & 0.2765 & 0.0184 & -0.1917 & -0.2193 & \\
\hline \multirow[t]{2}{*}{ Hinterland } & Simple regression & -0.4710 & 0.1879 & 0.5335 & 0.5230 & 0.3456 & \multirow{2}{*}{$\begin{array}{c}\mathrm{r}_{0.05}=0.7076 \\
\mathrm{n}=6\end{array}$} \\
\hline & Deviation regression & 0.7813 & 0.9989 & 0.3387 & -0.8957 & 0.9950 & \\
\hline
\end{tabular}

In the districts near South Coast and Mexico Gulf wood density was positive correlated with latitude of provenances and negative with annual mean temperature, which was consistent with the results in East Coast in Table 6. But wood basic density was positively related to longitude of provenances and negatively to annual rainfall and forstfree season, which were obvious different from the results in East Coast in Table 6. These indicated that wood of provenance of higher longitude districts far from East Coast planted near coast line area like our trial location would possess higher wood density, which was consistent with the research results of Byram (1988) and Tauer (1990). In the districts of Hinterland the results reflected the negative effect of povenance's latitude on wood density, i.e., the provenance near Mexico Gulf planted in our trial location 
would have higher wood density. Being a few numbers of provenances in Hinterland districts the result could be considered as a reference in its tree breeding.

In a word the local latitude of provenances was pronounced positively correlated with wood density in our trial location. This geographical variation pattern was distinct different from the north to south increase in wood density reported in the literature for stands of natural (Zobel and McElwee 1958, Mitchell 1964) and plantation (Teltbert and Jett 1981) and the northwest to southeast increase (Mitchell 1964), but complete agreement with the research results of plantation stands (Jackson 1962, Byram 1988, Tauer 1990, Jayawickrama 1997). A hypothesis given by Byram for the evident trend in his study was that genetic variation in wood density was controlled not only by the date of growth initiation, but also by the time of transition from springwood to summerwood production. Wood density could be determined by the length and amount of rainfall in the growing season and provenances from Southern districts would begin earlier in the spring. The radial growth cessation occurred at approximately the same time for all provenance and the southern sources made the transition to summerwood production at the same time or later than the northern sources. The southern sources would have a greater amount of springwood in the whole growth ring and a lower wood density. Jayawickrama's experiment showed that fast-growing southern and coastal sources of loblolly pine with lower wood density than northern and inland sources could be explained by a later transition to latewood, associated with a longer period of height growth, of the fast-growth sources.

Our provenances trial was conducted at lower latitude of Zhejiang Province in China. The reasons about wood density variation could exist as their explanation and experiment. But the inside property of the provenance could be other important factors. Usually trees of southern sources and east coastal sources grow faster than northern sources and hinterland. At the same length of growth season and summer the amount of springwood produced in the whole ring for southern and east coastal provenances should be higher than northern and hinterland provenances in spring. If the radial growth cessation occurred at approximately the same time for all provenance or the southern sources made the transition to summerwood production at the same time or later than the northern sources, the growth season of northern and hinterland provenances planted in the lower latitude districts near coastal line (like our trial location) should be longer than their indigenous districts and their latewood percentage should be increased, which would result in increase of wood density.

\section{TABLE 7}

\section{CORRELATION COEFFICIENTS OF TEACHEID ANATOMICAL FEATURES WITH DBH OF 310 TREES LOBLOLLY} PINE

\begin{tabular}{|c|c|c|c|c|c|c|}
\hline $\begin{array}{c}\text { Tracheid } \\
\text { length }\end{array}$ & $\begin{array}{c}\text { Tracheid } \\
\text { width }\end{array}$ & $\begin{array}{c}\text { Tracheid } \\
\text { diameter }\end{array}$ & $\begin{array}{c}\text { Tracheid } \\
\text { wall } \\
\text { thickness }\end{array}$ & $\begin{array}{c}\text { Tracheid } \\
\text { length } \\
\text { / width }\end{array}$ & $\begin{array}{c}\text { Double wall } \\
\text { thickness/ } \\
\text { diameter }\end{array}$ & $\begin{array}{c}\text { Tracheid } \\
\text { diameter } \\
/ \text { width }\end{array}$ \\
\hline-0.0681 & $0.3596^{* *}$ & $0.3635^{* *}$ & -0.0725 & -0.2211 & $-0.3104 * *$ & 0.1276 \\
\hline
\end{tabular}

\section{TABLE 8}

CORRELATION COEFFICIENTS OF WOOD BASIC DENSITY WITH TRACHEID ANATOMIC FEATURES FOR 310 TREES OF LOBLOLLY PINE PROVENANCE

\begin{tabular}{|c|c|c|c|c|c|}
\hline Tracheid features & $\mathbf{1}$ 3 rings & $\mathbf{4} \sim \mathbf{5}$ rings & $\mathbf{6} \sim \mathbf{7}$ rings & $\mathbf{1} \sim \mathbf{5}$ rings & $\mathbf{1} \sim \mathbf{9}$ rings \\
\hline Tracheid length & -0.1423 & -0.0480 & -0.0220 & -0.0870 & -0.0519 \\
\hline Tracheid width & $-0.2672^{* *}$ & $-0.2758^{* *}$ & $-0.2799^{* *}$ & $-0.2789^{* *}$ & $-0.3833^{* *}$ \\
\hline Tracheid diameter & $-0.3872^{* *}$ & $-0.3703^{* *}$ & $-0.3487^{* *}$ & $-0.3901^{* *}$ & $-0.4580^{* *}$ \\
\hline Tracheid length-width ratio & 0.0312 & $-0.1433^{* *}$ & $0.2465^{* *}$ & 0.1191 & 0.1082 \\
\hline
\end{tabular}

Correlation coefficients of DBH of 310 trees for 10-year-old loblolly pine with tracheid anatomical features were given in Table 7. At $99 \%$ statistical confidence level testing, DBH was significant positively correlated with tracheid width, tracheid diameter and distinct negatively related with ratio of tracheid double wall thickness to tracheid diameter $(\mathrm{n}=310$, $\mathrm{r}_{0.01}=0.1452$ ). These results reflected that fast growing of provenances or fast growing trees to a great extent attributed to the increase of tracheid width and tracheid diameter. That DBH was positively related to ratio of tracheid diameter to tracheid width and negatively to tracheid wall thickness showed that the tracheid wall thickness of fast growing trees or fast growing provenances did not increase in proportion as tracheid width and tracheid diameter increased. This would lead to the decrease in wood basic density. This result was demonstrated in Table 7 by correlation coefficients of wood density with tracheid anatomical features at different growth stage for loblolly pine provenances. There wood density was significant correlated negatively with tracheid width and tracheid diameter at different growth stage of loblolly pine. In Table 8 wood density for fast growing provenances with larger DBH and larger tree volume was smaller, for example, provenances of No15, No 13, 
No 16, No 25, No 10, No 31, No 29 and No 20. As pulpwood the decrease of wood density from fast provenances would be compensated with large tree growth increments and high yield per unit and the provenance selection might not be paid much attention to its wood density. But as construction timber the wood property like wood density should be taken into more consideration. These should be stressed in tree breeding and wood improvement of loblolly pine.

\section{CONCLUSION}

Based on the present study, the following conclusions can be drawn:

1 There were four radial variation patterns of wood basic density (BD) within 310 trees of 30 loblolly pine provenances, but the main pattern was a steadily increasing trend from pith to bark. The early-late correlation coefficient of BD for loblolly pine strengthens with trees age. The BD value of 5-year-old loblolly pine is able to predict that in 10 years old trees.

2 The BD mean change of 30 loblolly pine provenances is similar to normal distribution, the BD varies from 0.343 to $0.412 \mathrm{~g} / \mathrm{cm} 3$. The BD mean of the contrast provenance is $0.369 \mathrm{~g} / \mathrm{cm} 3$ and in medial level. Statistical difference in BD is found among 30 loblolly pine provenance. Further analyses show that the difference among trees within a provenance is greater than that among provenance and the environment has significant effects on the BD of loblolly pine. The broad heritability of $\mathrm{BD}$ for loblolly pine is 0.72 . The individual tree selection within a provenance was much better than that among different provenance.

3 Wood basic density (BD) of 30 exotic loblolly pine provenances was related positively to the provenance latitude. Longitude of provenance was related negatively to wood density in East Coast and positive to wood density in South Coast and Gulf. There was a tendency for BD of loblolly pine provenance to be lower from west to east and from north to south, this variation in plantation in a common environment turned out contrary to that of natural at different environment. The $\mathrm{BD}$ of loblolly pine provenance introduced from high latitude was greater than that from low latitude, but tree growth properties from low latitude were much faster than those from high latitude.

4 The BD mean of 310 trees at the stage of the same age was negatively related to the diameter at breast height and volume of these trees. Wood density was significant correlated negatively with tracheid width and tracheid diameter at different growth stage of loblolly pine. DBH was significant positively correlated with tracheid width, tracheid diameter and negatively distinct related to ratio of tracheid double wall thickness to tracheid diameter. That DBH was related positively to ratio of tracheid diameter to tracheid width and a little negatively to tracheid wall thickness showed that the tracheid wall thickness of fast trees or fast provenances did not increase in proportion as tracheid width and tracheid diameter increased. This would lead to the decrease in wood basic density. Better provenance selection for pulpwood and building lumber should be determined from both tree growth and wood properties.

\section{ACKNOWLEDGMENTS}

This paper was a part work of the project (IFS D/2260) funded by the International Foundation for Science in Sweden and by Natural Scientific Foundation of China (NSFC 30271056). We would like to express my thanks to Prof. Raul M De Albuquerque Sardinha, Prof. Jiang Zehui, Prof Li Minghe for their helpful suggestions in plan design, test methods and this paper writing. The direct great contributions have been made to this paper by Prof. Liu Zhaoxi and my graduates who are Miss Huang-Rui, Mr. Xiang Chunyun.

\section{REFERENCES}

[1] Byram T D, and Lowe W J. 1998, Specific gravity variation in a loblolly pine seed source study in the western Gulf region. Forestry Science, 34(3): 798-8032.

[2] Bunn E H. 1981, The nature of the resource. New Zealand Journal of Forstry. 26:162-169.

[3] de Guth E B. 1970, Variation of physical and chemical characteristics of several subtropical pinus species in North Argentina.. IDIA, 6:33-40.

[4] Jackson L W, Strickland R E 1962, Geographic variation in tracheid length and wood density of loblolly. Georige Rec Counc 8:1-4

[5] Jayawickrama K, McKeand S E and Jett J B. 1997, Date of earlywood-latewood transition in provenances and families of loblolly pine, and its relation to growth phenology and juvenile wood specific gravity. Can. J. For. Res. 27:1245-1253.

[6] Jett J B, Guiness W M . 1992, Growth and wood properties in a Carolina sandhills pine seed source study. Southern-Journal-ofApplied-Forestry. 1992, 16: 4, 164-1696.

[7] Lantz V W, and Hofmann J G,1969, Geographic variation in growth and wood quality of Loblolly Pine in North Carolina. Proceedings of the 10th Southern Conference on Forest Tree Improvement. Houston,Texas , p175-188 
[8] Liu Qinghua, hang Rui, Jin Guoqing. Variation of Ring Width and Wood Basic Density and Early Selection of Pinus massoniana Provenances[J]. Scientia Silvae Sinicae, 2010, 46(5): 49-54.

[9] Loo C C, Tauer and Mcnew R W. 1985, Genetic variation in the time of transition from juvenile to mature wood in loblolly pine. Silvae Genetica,34(1)14 - 19

[10] Koch P. 1972 Unitilization of southern pines. USDA For. Serv.Agric. Handb.pp1630.

[11] Kimura Junji , Fujimoto Takaaki. Moeling the effects of growth rate on the intra-tree variation in basic density in hinoki cypress..Journal of wood science 60(5), 305-312, 2014

[12] Panshin A J, Zeeuw C. Textbook of wood technology, $4^{\text {th }}$ ed, New York, McGraw-Hill, 1980

[13] Peng Zigan. 1992, Studies on provenance trial of slash pine and loblolly pine(in chinese). First Edition , Beijing Science and Technology Publishing House. China Beijing, 181pp.

[14] SAS Institute Inc. 1988a.SAA user,s guide: basic, version 6.03 edition. SAS Institute Inc., Cary, NC.

[15] S K Sharma,S R Shukla and S. Shashikala. Axial variations in anatomical properties and basic density of Eucalypt urograndis hybrid. J.For.Res.(2015)26(3):739-744

[16] Talbert J T, and Jett J B. 1981, Regional specific gravity values for plantation grown loblolly pine in soutreastern of United States. For. Sci. 27:801-807

[17] McLemore B F, Crow A B and Wakeley, P C. 1961, Dry-matter content of Loblolly Pine needles appears unrelated to geographic seed source. For. Sci. 7 (4), 1961 (373-5).

[18] Takeuchi Ryosuke, Wahyudi Imam , Aiso Haruna.Wood properties related to pulp and paper quality in twoMacaranga species naturally regenerated in secondary forests, Central Kalimantan, Indonesia. Tropics 25(3), 107-115, 2016 (JAPAN SOCIETY OF TROPICAL ECOLOGY)

[19] Tauer C G and Loo Dinkins J A. 1990, Seed source variation in specific gravity of loblolly pine grown in a common environment in Arkansas. Forestry Science, 36( 4): 1133-1145

[20] Thor E. 1967, A ten-year-old Loblolly Pine seed source test in Tennessee. J. For. , 65 (5):326-327

[21] Zobel B J. 1958, Natural variation in wood specific gravity of loblolly pine and analysis of contributing factors. Tappi 41(1)14-19

[22] Zobel B J and J P van Buijtenen. 1989, Wood variation, its cause and control. Springer-Verlag. 